\title{
Pemanfaatan Tepung Tulang Ikan untuk Bidang Pertanian oleh Masyarakat Desa Tanjung Keramat Gorontalo
}

\author{
Desi Arisanti ${ }^{1 *}$, Ika Okhtora Angelia ${ }^{1}$, Amiruddin $^{1}$ \\ ${ }^{1}$ Program Studi Teknologi Hasil Pertanian Politeknik Gorontalo \\ Jl. Mukhlis Rahim Panggulo Barat Bone Bolango Provinsi Gorontalo \\ *E-mail : desiarisanti@poligon.ac.id \\ DOI: https://doi.org/10.21107/pangabdhi.v7i1.9992 \\ Naskah diterima 18 Februari 2021, Revisi 26 Maret 2021, Terbit 29 April 2021
}

\begin{abstract}
Tuna fish bones are by-products or waste from fisheries. Not many people have applied tuna fishbone in agriculture. In fact, tuna fish bones can be used as organic fertilizer and animal feed which can be processed into bone meal. According to this condition, the Community Service Team from the Agricultural Product Technology Study Program took the initiative to assist the community to take advantage of it. This activity is carried out in Tanjung Kramat Village, which is one of the largest tuna producing areas in Gorontalo. This activity includes material presentation, discussion and demonstration of making fish bone meal. From the results of these activities, enthusiasm from the community and local village officials can be seen to develop it into organic fertilizer and animal feed.
\end{abstract}

Keywords : tuna fish bone, community services, animal feed, organic fertilizer

\section{PENDAHULUAN}

Kondisi geografis Provinsi Gorontalo yang dikelilingi oleh perairan menyimpan potensi untuk dikembangan dan dimanfaatkan secara luas bagi masyarakat. Salah satu wilayah yang mempunyai potensi ini adalah Desa Tanjung Kramat Kecamatan Hulonthalangi. Desa ini merupakan salah satu wilayah yang memiliki potensi ikan tuna terbesar di Gorontalo. Rata-rata pekerjaan masyarakat di desa ini adalah sebagai nelayan.

Limbah ikan tuna berupa tulangnya masih jarang dimanfaatkan oleh masyarakat maupun pemerintah setempat. Limbah padat yang dihasilkan dari industri pengolahan ikan maupun kegiatan rumah tangga cukup besar, salah satunya ialah tulang ikan. Limbah perikanan yang berasal dari tulang ikan tuna sebagai salah satu contoh limbah yang belum diolah dan dimanfaatkan secara maksimal (Lestari dan Dwiyana, 2016). Padahal berdasarkan hasil penelitian menjelaskan masih tingginya kandungan hara makro dan mikro di dalam tulang ikan (Imra et al., 2019). Kandungan tertinggi tulang ikan tuna adalah kalsium. Kalsium secara umum sering dijumpai dalam bentuk kapur kalsit atau dolomit. Penggunaan kapur an-organik secara terus menerus dapat menyebabkan kerusakan kesuburan tanah (Amiroh, 2017). Sehingga perlu adanya inovasi penganti kapur anorganik ini agar aman dan tidak menyebabkan penurunan kemampuan tanah sebagai media tanm. Salah satu potensi tulang ikan tuna yang bisa dimanfaatkan dalam bidang pertanian adalah memanfaatkannya menjadi pupuk organik berupa kapur organik dalam bentuk tepung tulang ikan maupun sebagai pakan ternak.

Minimnya pengetahuan masyarakat setempat dalam memanfaatkan tulang ikan tuna ini bisa dilatarbelakangi belum adanya transfer pengetahuan atau teknologi tepat guna. Oleh karenanya, melihat kondisi ini Tim Pengabdian dari Program Studi Teknologi Hasil Pertanian Politeknik Gorontalo mencoba melakukan pendampingan dalam proses pembuatan tepung tulang ikan tuna sebagai penganti kapur anorganik (Sutarman, 2016).

Tepung tulang ikan ini nantinya bisa dimanfaatkan menjadi bahan tambahan dalam pembuatan pupuk organik maupun sebagai pakan ternak. Apalagi saat ini ibu-ibu rumah tangga sedang viral dengan menanam bunga. Media tanamnya bisa dengan memanfaatkan sampah rumah tangga dan ditambahkan tepung tulang ikan sebagai sumber kalsium dan fosfor serta berfungsi juga sebagai kapur organik. 
Kandungan hara makro tepung tulang ikan tuna berupa kalsium sekitar 39-40\%.

Sehingga berdasarkan latar belakang potensi tulang ikan tuna di Desa Tanjung Kramat nantinya bisa dikembangkan agar bernilai ekonomis. Apabila ingin dikembangkan dalam skala industri rumah tangga maka peran pemerintah setempat secara kontinu juga diharapkan guna membantu masyarakatnya dalam meningkatkan taraf hidup keluarga dan sebagai salah satu bentuk partisipasi dalam menjaga linkungan sekitar dari cemaran bau limbah ikan.

\section{METODE}

Program Pengabdian Masyarakat ini dilaksanakan di Kantor Desa Tanjung Kramat Kecamatan Hulonthalangi pada bulan Februari 2021 dengan melibatkan masyarakat desa yang terdiri dari ibu-ibu rumah tangga dan para nelayan setempat serta aparat desa. Peserta yang mengikuti kegiatan PKM ini berjumlah lebih kurang 20 orang dan kebanyakan adalah ibu-ibu rumah tangga yang memiliki latar belakang ekonomi yang tidak mampu. Sebagian besar peserta berprofesi sebagai nelayan dan petani. Kegiatan ini sangat bermanfaat bagi peserta yaitu dengan menjarkan bagaimana memanfaatkan limbah menjadi barang yang bermanfaat. Pada kegiatan ini terdiri dari beberapa tahapan yaitu penyajian materi berupa pemaparan slide presentasi, diskusi dan demo pembuatan tepung tulang ikan.

Sebelum pemberian materi dan demo produk, kegiatan ini diawali dengan sambutan dari pemerintah setempat yang disampaikan langsung oleh Kepala Desa Tanjung Kramat. Setelah sambutan dilanjutkan dengan pemaparan materi dan diskusi serta demo produk pembuatan tepung tulang ikan Tuna. Alat-alat yang digunakan dalam demo pembuatan tepung tulang ikan adalah grinder, pisau, loyang, oven, panci, kompor dan panci presto. Bahan-bahan yang digunakan berupa tulang ikan dan air.

\section{HASIL DAN PEMBAHASAN}

Berdasarkan Kegiatan PKM yang dilakukan terlihat antusiasi dari peserta setelah penyajian materi oleh Tim Pengabdian. Hal ini bisa dilihat dari penjelasan yang diberikan yang mampu dipahami oleh peserta melalui pengunaan bahasa daerah setempat yang disisipkan ketika memberikan materi.

Pemerintah daerah setempat melalui kegiatan ini akan menindak lanjuti agar limbah ikan yang menjadi sampah yang mengotori lingkungan dapat dimanfaatkan secara terus menerus. Pemerintah Desa Tanjung Kramat juga berinisiatif akan memfokuskan secara rutin dan akan mengaplikasikannya dalam pembuatan pupuk organik sebagai tambahan kandungan hara dalam tanah.

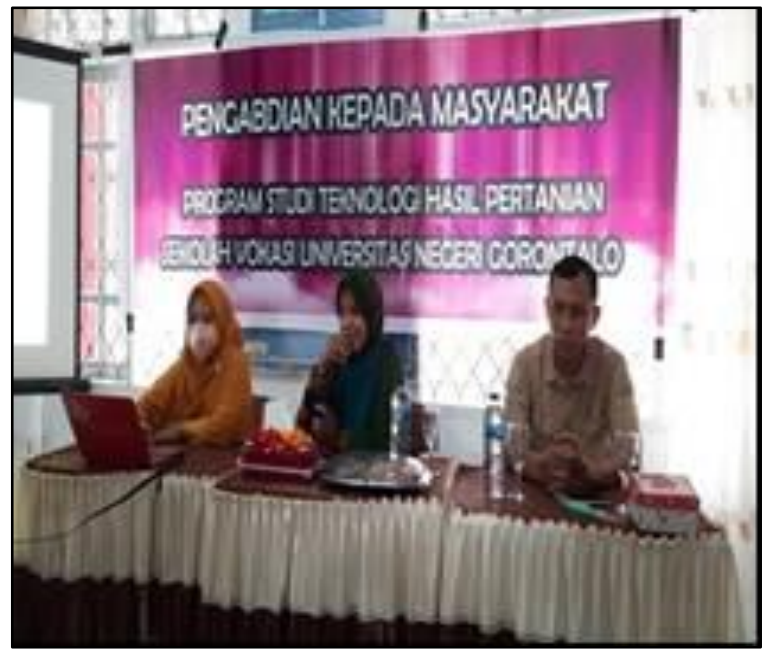

Gambar 1. Penyajian Materi Pelatihan

Limbah ikan dapat dimanfaatkan sebagai bahan baku pupuk organik lengkap karena tinggi akan kandungan nitrogen $(\mathrm{N})$, fosfor $(\mathrm{P})$, dan kalium (K) sesuai yang dibutuhkan (Ditjen Perikanan Budidaya, 2015). Kandungan tepung tulang ikan dikenal sebagai unsur mineral. Mineral tersebut merupakan salah satu komponen dalam bahan makanan. Komponen ini terdiri dari kalium, fosfor, natrium, magnesium, kalsium, besi, mangan, dan tembaga (Imra et al., 2019). Menurut Lingga et al., (2016), kompos yang mengandung Kalsium dalam jumlah cukup mampu memacu aktivitas mikroorganisme dalam menguraikan bahan organik.

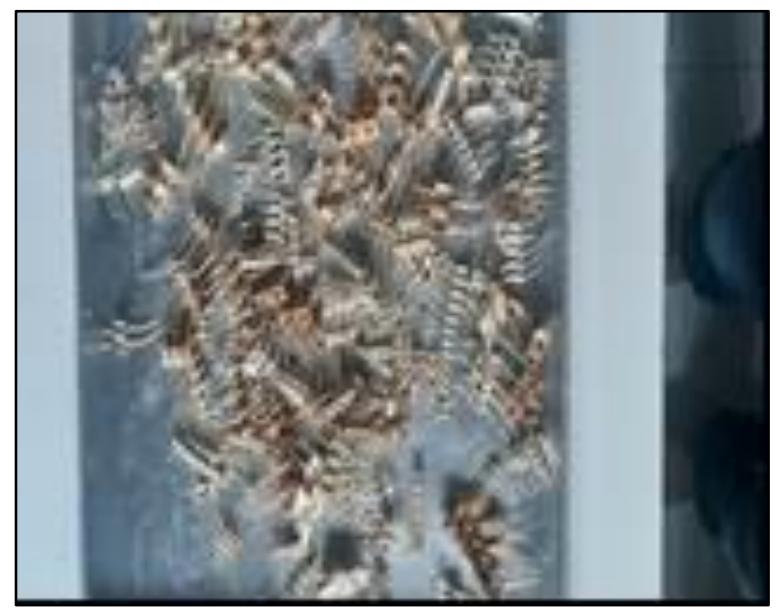

Gambar 2. Pengovenan Tulang Ikan Tuna pada Suhu $85^{\circ} \mathrm{C}$ Selama 8 Jam 
Proses pembuatan tepung tulang ikan pada kegiatan PKM ini dilakukan cukup memperhatikan tindakan sanitasi dan higienis. Salah satu contohnya adalah penggunaan ikan yang segar dalam proses pembuatannya serta menggunakan sarung tangan serta air bersih dan mengalir. Tujuannya adalah untuk menghindari masih tertinggalnya bakteri patogen pada tulang ikan serta mempertahankan kualitas tepung ikan yang dihasilkan. Sehingga tepung tulang ikan tuna ini dapat diaplikasikan pada proses pembuatan pakan ternak dan pupuk.

Pada saat demo pembuatan tepung tulang ikan tuna dijelaskan juga apabila ada peralatan yang tidak dimiliki di rumah tangga masing-masing. Maka bisa dicarikan alternatif penganti seperti panci presto yang tidak semua masyarakat punya maka bisa diganti dengan perebusan tulang ikan yang cukup lama sekitar 5-6 jam. Hal ini bertujuan untuk memperlunak ikan apabila akan dihaluskan. Kemudian juga pada saat demo pemateri juga menjelaskan tujuan dari perebusan tulang ikan tuna kepada peserta. Perebusan ini bertujuan untuk menghilangkan lemak dan minyak yang mungkin masih menempel pada tulang ikan. Berdasarkan penelitian (Almatsier, 2002) menjelaskan bahwa lemak yang menempel pada proses pembuatan tulang ikan dapat membuat kualitas tepung menjadi menurun sehingga umur simpan dari tepung tidak akan lama.

\section{KESIMPULAN}

Berdasarkan kegiatan PKM yang telah dilaksanakan dinilai cukup baik dan lancar dan diharapkan agar ada tindak lanjut secara kontinue dari Tim Pengabdian dan kerjasama yang baik dengan pemerintah setempat.

\section{DAFTAR PUSTAKA}

Almatsier S. (2002). Prinsip Dasar Ilmu Gizi. Jakarta: PT. Gramedia Pustaka Utama.

Ditjen Perikanan Budidaya. (2015). Pemanfaatan Limbah Pupuk Organik. Jakarta.

Imra, M., Fadnan, A., Abdiani, I.R \& Irawati, H. (2019). Karakteristik Tepung Tulang Ikan Bandeng (Chanos chanos) dari Limbah Industri Baduri Kota Tarakan. Jurnal TechnoFish. Vol 3 (2). 60-69 pp.

Lestari, W.A \& Dwiyana, P. (2016). Pemanfaatan Limbah Tulang Ikan Tuna (Thunnus $s p$ ) dalam Bentuk Tepung pada Pembuatan Stick. Jurnal Ilmu Kesehatan. Vol 8 (2). 46-53 pp.

Lingga, P \& Marsono. (2013). Petunjuk Menggunakan Pupuk. Jakarta: Penebar Swadaya.

Setyono, B. (2012). Pembuatan Pakan Buatan. di Unit Pengelola Air Tawar. Sagu. Vol 3 (1). 20$27 \mathrm{pp}$.

Sutarman, I.W. (2016). Pemanfaatan Limbah Industri Pengolahan Kayu di Kota Denpasar. Jurnal Pasti. Vol 1 (2). 